\title{
Seasonal Influence on Sexual Behaviour Score of Gir Bulls
}

\author{
G.B. Solanki ${ }^{*}$, F.S. Kavani' ${ }^{2}$, S.H. Talekar ${ }^{3}$, A.R. Ahlawat ${ }^{3}$, \\ H.H. Savsani ${ }^{3}$ and P.M. Gamit ${ }^{1}$ \\ ${ }^{1}$ Cattle Breeding Farm, Junagadh Agricultural University, Junagadh, India \\ ${ }^{2}$ Former Professor and Head, Dept. of ARGO, Veterinary College, Anand Agricultural \\ University, Anand, India \\ ${ }^{3}$ College of Veterinary Science and A.H., Junagadh Agricultural University, Junagadh, India \\ *Corresponding author
}

\begin{tabular}{|l|}
\hline K e y w o r d s \\
Gir bulls, Seasonal \\
influence, \\
temperament, \\
Penile erection, \\
Protrusion, Thrust, \\
Reaction time, \\
Flehmen reaction \\
\hline Article Info \\
\hline $\begin{array}{l}\text { Accepted: } \\
\text { 24 May } 2019 \\
\text { Available Online: } \\
\text { 10 June 2019 }\end{array}$ \\
\hline
\end{tabular}

A B S T R A C T

Studies on sexual behaviour as such, and the documented reports on the influence of seasons on these aspects are meager in Gir bulls, the world famous milch purpose cattle breed of India. These indices could be used in selection and culling of Gir bulls in the breeding program. The study was carried out on six Gir bulls (4-6 years) located at Cattle Breeding Farm, J.A.U. Junagadh for a period of 8 months during summer and winter. The seasonal variations and correlations amongst the sexual behaviour traits were studied. The effect of season on individual bulls for these parameters was also studied. A total of 96 observations were availed at fortnightly interval. The mean temperament (0-5 scale), libido (0-9 scale), penileerection ( $0-4$ scale), protrusion (0-4 scale), intensity of thrust ( $0-4$ scale), reaction time (sec.) and Flehmen reaction $(0,1)$ during summer were $1.77 \pm 0.08$, $5.23 \pm 0.22,2.73 \pm 0.07,2.68 \pm 0.07,3.19 \pm 0.11,153.54 \pm 4.82$ and $0.46 \pm 0.07$, respectively, while the respective values in winter season were $2.08 \pm 0.06,5.96 \pm 0.22,3.02 \pm 0.06$, $2.96 \pm 0.43,3.40 \pm 0.39,128.09 \pm 4.24$ and $0.56 \pm 0.07$. There were significant differences among bulls for these traits in both the seasons. However, in general, summer significantly exerted an adverse effect on the sexual behaviour of Gir bulls, while winter was the favoured season. Temperament, libido, penile erection, penile protrusion, and intensity of thrust were significantly and positively correlated among each other, and negatively with reaction time and Flehmen reaction. It could be concluded from the present study that the Gir bulls had good sexual behaviour scores throughout the year, However, bulls showed better sexual behaviour in winter as compared to summer.

\section{Introduction}

Indigenous breeds of cattle are an integral part of traditional agriculture and are progressively diluted due to crossbreeding programme and mechanization of agriculture in India.
Indigenous cattle contribute 50 per cent of milk production in India and are able to withstand the extreme weather conditions (FAO, 2012). The Gir is a famous milch cattle breed of India and are famous for their tolerance to stress conditions and resistance to 
various tropical diseases. The demand for frozen semen of elite indigenous bulls is increasing throughout the country due to its milk productivity, adaptability, disease resistance, heat tolerance, and survivability on poor feed and fodder resources. To achieve the optimum target of quality frozen semen production with better fertility breeding soundness evaluation (BSE) of bulls is important, for which sexual behaviour and semen quality of breeding bulls need to be studied along with their relationship. The sexual behaviour traits reflect the reproductive efficiency of breeding bulls and have paramount importance in a breeding program. Libido in bulls is a heritable trait. Aggressive and efficient breeders tend to have offspring that are also good breeders. Sexual behaviour is a very complex phenomenon, controlled by the endocrine constitution of an animal, influenced by the social environment, sensory capacities and sexual stimuli (Naskar and Nagpaul, 2005). Joshi and Kharche (1992) reported that the intensity of sexual expression not only reflects the sex drive (libido) but also the seminal attributes of bull. Also, sexual behaviour stimulation could increase spermatozoa production (Sholikah et al., 2018).

The season in which semen is collected is likely to have an important effect on ejaculate quality, although the results from previously published studies in cattle are somewhat ambiguous. Specific consideration to the surrounding environmental conditions particularly temperature and humidity should be paid to minimize their negative influence directly or indirectly on semen production and other related physiological functions of the breeding bulls (Ahirwar et al., 2018). The use of superior male animals with high genetic potential can further improve the productivity of this breed. In-depth study of the sexual behaviour in Gir bull is lacking. These indices could be used in selection and culling of Gir bulls in the breeding programme. It will be of great significance, to acquire pertinent information on the sexual behaviour in Gir bull during different seasons of the year to predict the reproductive efficiency of the bull.

\section{Materials and Methods}

A total of 6 Gir (Bosindicus) bulls, aged 5 to 6 years, maintained at a semen collection station, Cattle Breeding Farm, Junagadh Agricultural University, Junagadh, were used in the study during summer and winter season. All the bulls were in good health under uniform veterinary care and identical sanitary conditions. Before the inclusion of bulls in the experiment, they were examined and screened for their normal external and internal reproductive organs.A total of 8 observations were taken at fortnight interval from each bull in each season.

\section{Temperament score}

The behavioural temperament was scored as per the scorecard developed by Hearnshaw and Morris (1984) on a 0-5point scale (Table 1).

\section{Libido score}

A 10-point scale scorecard developed by Chenoweth (1981) was used to record the libido (Table 2).

\section{Penile erection, protrusion and intensity of thrust}

Erection and protruding of penis during seeking and ejaculatory thrust were observed and scored as described by Joshi and Kharche (1992) (Table 3).

\section{Reaction time}

Reaction time is the time lapse between the exposures of bull to the dummy bull till 
successful ejaculation. Reaction time was recorded in seconds.

\section{Flehmen reaction}

A score of "1" was given if the bull exhibited Flehmen response, while a score of "0" was given if no response was obtained.

\section{Results and Discussion}

The mean values of sexual behaviour traits, seasonal variations and the effect of bull and season on these traits of Gir bulls are depicted in Table 4 to 5 . For the breeding soundness evaluation of breeding bull, the evaluation of sexual behaviour and their relationship is very much important. It will minimize the chances of inclusion of problem bull in a breeding program as well it allows the breeder to provide adequate sexual preparation before semen collection. Libido, reaction time and total time taken for the successful mount are the important parameters to judge sexual behaviour of breeding bulls. The relationship between sexual behaviour traits in Gir bulls are depicted in Table 6 and Figure 1.

\section{Temperament score}

The mean temperament scores of Gir bulls were $1.77 \pm 0.08$ and $2.08 \pm 0.06$ during summer and winter, respectively (Table 4). The effect of season on temperament score was found significant $(P<0.01)$ with higher values recorded during winter than the summer season. There was no significant difference among bulls for temperament score in either of the season. However, one bull showed highly significant $(P<0.01)$ difference between two seasons (Table 5).

The bulls were docile and manageable at the time of semen collection and the score ranged from docile to little aggressive. Average temperament score $(0-5$ scale) indicated that
Gir bulls showed slight excitement with straining and paddling but without the kick. Similar temperament scores in Sahiwal (Panwar and Nagpaul, 1989) and Kankrej (Deka, 2015 and Rathod, 2018) bulls have also been reported. Temperament score recorded in the present study was, however, higher than that recorded earlier in Sahiwal bulls (Kumar and Nagpaul 1995; Elrabie et al., 2008; Reddy and Sasikala, 2013). Nevertheless, higher temperament scores than the present ones in Karan Swiss and Karan Fries bulls (Panwar and Nagpaul, 1989; Adwani, 1992)and in Jersey $x$ Sahiwal crossbred bulls (Reddy and Sasikala, 2013) have been reported.

The effect of season on temperament score was found significant $(\mathrm{P}<0.01)$ with higher values recorded during winter than the summer season. The effect of season on temperament score has been reported to be non-significant in Kankrej bulls (Deka, 2015). However, Rathod (2018) found significantly lower temperament score during monsoon followed by winter and summer in Kankrej bulls.

The correlation study revealed that temperament was highly $(P<0.01)$ positively correlated with penile protrusion score $(\mathrm{r}=0.292)$ and intensity of thrust $(\mathrm{r}=0.252)$ and negatively $(P<0.01)$ correlated with reaction time $(\mathrm{r}=-0.287)$. It also had a significant $(P<0.05)$ positive correlation with penile erection score $(\mathrm{r}=0.182)$. However, the correlation of Temperament was weak with other traits. Results indicated that bull having better temperament tend to show better penile protrusion, the intensity of thrust, penile erection and had less reaction time. These were better signs for semen collection and bull having better temperament can be selected for semen collection. These findings also corroborate well with the significant negative correlation $(P<0.05)$ with reaction 
time reported in Karan Swiss (Panwar and Nagpaul, 1989), Karan Fries (Panwar and Nagpaul, 1989), Kankrej bulls (Rathod, 2018) and in Sahiwal bulls (Panwar and Nagpaul, 1989; Kumar, 1993). Sexual aggressiveness had a highly significant positive correlation with LB and similar correlation to that of the present study but with non-significant negative correlation with RT has been reported in Sahiwal bulls (Singh et al., 2015). However, Temperament had significant $(P<0.05)$ positive weak correlation with total time taken to mount in Kankrej bull (Deka, 2015). Previous studies reported that Temperament and Libido of bulls have no correlation in crossbred and Sahiwal bulls (Panwar and Nagpaul, 1989; Adwani, 1992; Kumar, 1993).

\section{Libido score}

The mean libido score was $5.23 \pm 0.22$ and $5.96 \pm 0.22$ during summer and winter, respectively (Table 4). Libido score was significantly $(P<0.01)$ higher during winter season as compared to summer. There was highly significant difference $(P<0.01)$ among bulls for libido score, while only one bull showed significant seasonal difference $(P<0.01)$, with the value being higher in winter than summer season (Table 5).

The bulls were very active during semen collection and exhibited pronounced libido as evident from their score, indicating their better reproductive potential. Mean libido score and its range indicated that Gir bulls required about two false mounts for successful service with no further sexual interest. Similarresults in Karan Fries (Panwar and Nagpaul, 1989) and in daily parading crossbred bulls (Adwani, 1992) have been reported. Whereas, higher mean libido score than that of the present study was reported in Sahiwal bull (Panwar and Nagpaul, 1989; Kumar and Nagpaul, 1995; Mandal and
Tyagi, 2004; Elrabie et al., 2008; Reddy and Sasikala, 2013), Frieswal bulls (Mandal et al., 2008), Jersey x Sahiwal bull (Reddy and Sasikala, 2013); Kankrej bull (Deka, 2015; Rathod, 2018). While, comparatively lower mean libido score was reported in Karan Swiss (Panwar and Nagpaul, 1989; Pal et al., 2012); Sahiwal (Ahmad et al., 2005), Karan Fries (Panwar and Nagpaul, 1989), Cholistanibulls (Mahmood et al., 2013) and Madura bulls (Sholikah et al., 2018).

Mean libido score was significantly higher $(P<0.01)$ during the winter season as compared to summer. While, significantly lower $(P<0.05)$ libido score was reported during the summer season in Sahiwal bull (Ahmad et al., 2005). Libido score was nonsignificantly higher during winter in Frieswal bulls (Mandal et al., 2008) and Cholistani bulls (Mahmood et al., 2013). On the contrary, a significantly higher libido score during summer as compared to winter and monsoon season has been reported in Kankrej bulls (Deka, 2015; Rathod, 2018).

Variations in libido score might be attributed to the different managemental conditions, experimental location, breed and species. Gir bulls showed very good libido score ranging from 5 to 6 (0-9 scale) throughout the experimental period. This is the desired characteristics of breeding bulls under semen collection and might be due to better nutrition, management, handling and regular exercise. Bulls with better libido can produce a sufficient number of viable sperm through multiple ejaculates in short time. Use of bulls with better libido has been shown to benefit pregnancy rates, time of conception, length of calving seasons, and homogeneity of calves at weaning and more efficient use of workers (Godfrey and Lunstra, 1989). Poor libido is ascribable as an irrefutable cause of subfertility among the zebu breeds of cattle (Mathur et al., 2002). 
Libido score had significant $(P<0.01)$ positive correlations with penile erection $(\mathrm{r}=0.470)$ and protrusion $(\mathrm{r}=0.474)$ and a significant $(\mathrm{p}<0.05)$ positive correlation with thrust $(\mathrm{r}=0.218)$. While, it was significantly $(P<0.01)$ negatively correlated with reaction time ( $\mathrm{r}=-0.381)$. Libido score had a nonsignificant negative correlation with Flehmen reaction. In Sahiwal bulls, it was observed that libido had no correlation with penile erection, but similar to present observation it had a significant positive correlation with penile protrusion and thrust (Kumar, 1993). Libido score was significantly $(P<0.01)$ and negatively correlated with reaction time. Similar correlations in Sahiwal (Singh et al., 2015) and Kankrej bulls (Rathod, 2018) have been reported. In conflict with the present findings, significant $(P<0.01)$ positive correlation between libido and reaction time in Kankrej bull (Deka, 2015) has been reported. Correlation of libido and reaction time was reported to be significant in crossbred and Sahiwal bulls (Panwar and Nagpaul, 1989), while it was found nonsignificant in Sahiwal bulls (Kumar, 1993) and non-significant negative in crossbred bulls (Pal et al., 2012). Results indicated that bull having better libido tends to show better penile erection, penile protrusion, the intensity of thrust, as well as taking less time to react dummy and donate semen with lesser frequency of Flehmen reaction. Hence, Gir bull can be selected on the basis of libido score at semen bank to improve semen collection and to reduce the time during semen processing.

\section{Penile erection score}

The mean value for erection score was significantly $(P<0.01)$ higher during the winter season $(3.02 \pm 0.06)$ as compared to summer season $(2.73 \pm 0.07)$ (Table 4$)$. There was highly significant difference $(P<0.01)$ among bulls for penile erection score, while only two out of six bulls showed significant seasonal difference $(P<0.01)$, with the value being higher in winter than summer season (Table 5).

The mean erection score indicated that all the bulls showed good penile erection. Similar mean erection score was reported earlier in Sahiwal bulls (Kumar and Nagpaul, 1995; Singh et al., 2015). Whereas, lower mean erection scores than present ones have also been reported in Sahiwal (Mandal and Tyagi, 2004; Elrabie et al., 2008; Reddy and Sasikala, 2013; Elrabie, 2017) and Frieswal bulls (Mandal et al., 2008). While higher mean erection score than that of the present study was noted in crossbred bulls (Joshi and Kharche, 1992), Jersey x Sahiwal crossbreds (Reddy and Sasikala, 2013) and Kankrej bulls (Deka, 2015; Rathod, 2018).

Erection score was observed to be significantly higher $(P<0.01)$ during winter as compared to summer season in Gir bulls. However, a non-significant seasonal variation in erection score was found in Kankrej bulls by Deka (2015), while Rathod (2018) observed significantly different $(P<0.01)$ erection scores during all three seasons in Kankrej bulls, the values being maximum in winter season. Gir bulls showed good erection score throughout the study indicating better sexual behaviour.

Erection score had positive significant $(P<0.01)$ correlations with penile protrusion $(\mathrm{r}=0.498)$ and thrust $(\mathrm{r}=0.342)$. It was significantly and negatively correlated with reaction time ( $\mathrm{r}=-0.424, P<0.01)$ and Flehmen reaction $\quad(\mathrm{r}=-0.194, \quad P<0.05)$. Similar correlations in Kankrej bulls (Deka, 2015; Rathod, 2018) and non-significant positive correlations in Sahiwal bulls (Singh et al., 2015) have been reported. Rathod (2018) also reported that erection score was highly significantly $(P<0.01)$ and negatively 
correlated with reaction time and Flehmen reaction in Kankrej bulls. However, no such correlation was reported in Kankrej (Deka, 2015) and Sahiwal bulls (Singh et al., 2015) in other studies.

\section{Penile protrusion score}

The Gir bulls showed normal penile protrusion with score ( $0-4$ scale) ranging from 2.73 to 2.89 . At few occasions, the protrusion was much pronounced in a way leading to collecting cone turn inward and the tube got detached from cone within the insulating bag or thrown away, which needed in reducing the pressure within the artificial vagina (AV) at such occasions. The mean protrusion score during summer and winter was found to be $2.68 \pm 0.07$ and $2.96 \pm 0.43$, respectively (Table 4). Protrusion score was significantly $(P<0.01)$ higher during winter as compared to summer season.

There was significant difference $(P<0.01)$ among bulls for penile protrusion score only in summer season, while only two out of six bulls showed significant seasonal differences $(P<0.01)$ in penile protrusion score, with the value being higher in winter than summer season (Table 5).

Fig.1 Seasonal variations in sexual behaviour score of Gir bulls during

Summer and winter seasons

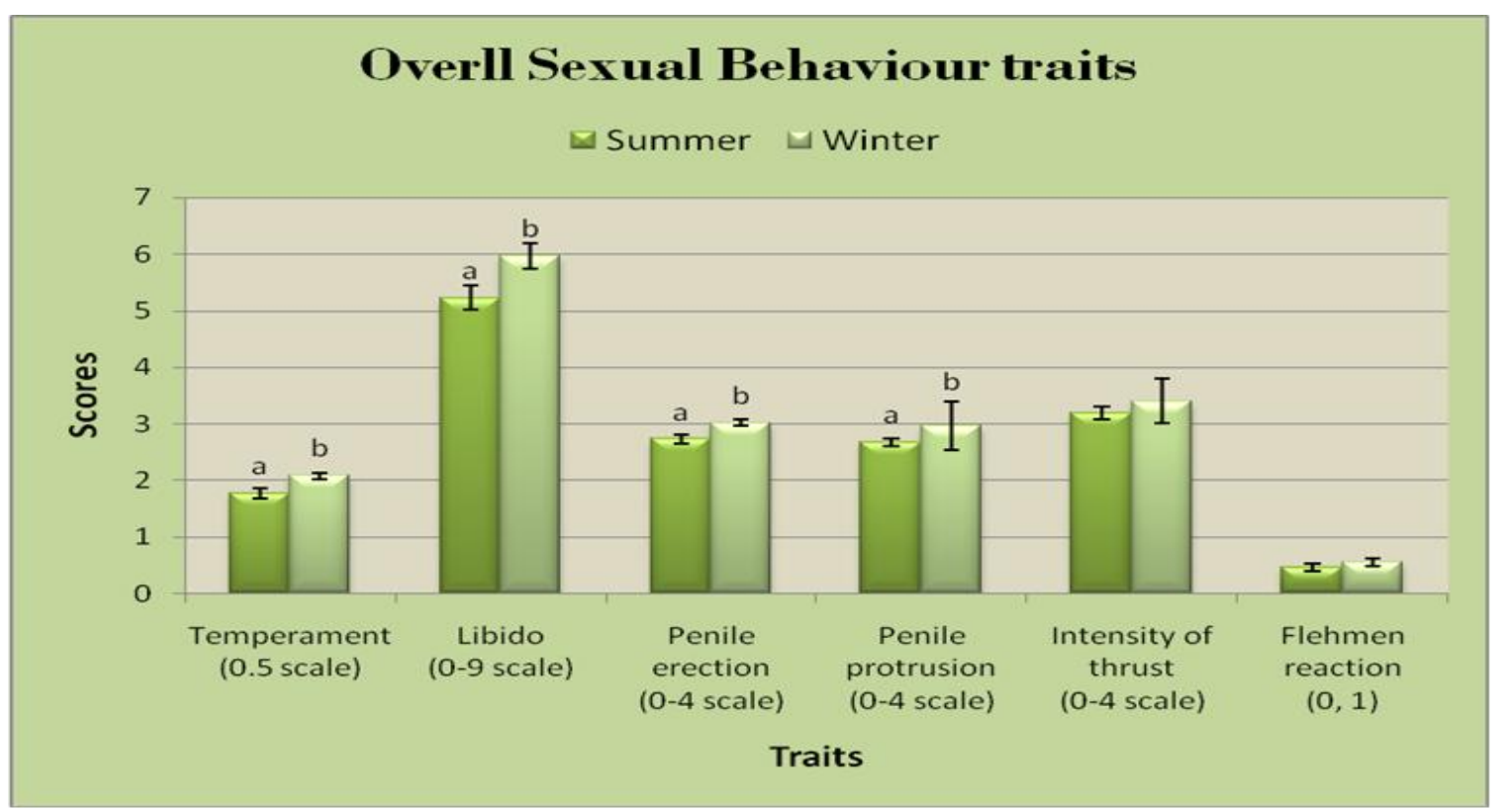

Table.1 Temperament scorecard for breeding bulls

\begin{tabular}{|c|l|c|}
\hline Sr. No. & \multicolumn{1}{|c|}{ Description } & Score \\
\hline $\mathbf{1 .}$ & Stand very quietly, offers no resistance, only casual fair switching & 00 \\
\hline $\mathbf{2 .}$ & Generally quiet, offers taken resistance, steady movement & 01 \\
\hline $\mathbf{3 .}$ & Slightly excited movement, straining and paddling, may kick & 02 \\
\hline $\mathbf{4 .}$ & Excited vigorous, abrupt movement, straining and paddling, may kick & 03 \\
\hline $\mathbf{5 .}$ & Very disturbed, frightened, wild movements, many jumps and falls down in a crate & 04 \\
\hline $\mathbf{6 .}$ & Unmanageable and dangerous & 05 \\
\hline
\end{tabular}


Table.2 Libido scorecard for breeding bulls

\begin{tabular}{|c|l|c|}
\hline Sr. No. & Description & Score \\
\hline $\mathbf{1 .}$ & Bull showed no sexual interest or no mounting & 00 \\
\hline $\mathbf{2 .}$ & One mount or mounting attempt, no service & 01 \\
\hline $\mathbf{3 .}$ & Two mounts or mounting attempts, no service & 02 \\
\hline $\mathbf{4 .}$ & More than two mounts or mounting attempts, no service & 03 \\
\hline $\mathbf{5 .}$ & $\begin{array}{l}\text { Two mounts, one service followed by sexual interest including mounts } \\
\text { and mounting attempts }\end{array}$ & 04 \\
\hline $\mathbf{6 .}$ & $\begin{array}{l}\text { More than two mounts or mounting attempts and one service followed by } \\
\text { sexual interest }\end{array}$ & 05 \\
\hline $\mathbf{7 .}$ & Two mounts, one service, no further sexual interest & 06 \\
\hline $\mathbf{8 .}$ & One mount, one service, no further sexual interest & 07 \\
\hline $\mathbf{9 .}$ & $\begin{array}{l}\text { One mount, one service followed by sexual interest including mounts or } \\
\text { mounting attempts }\end{array}$ & 08 \\
\hline $\mathbf{1 0 .}$ & More than two mounts and one service, no further sexual interest & 09 \\
\hline
\end{tabular}

Table.3 Scorecard for penile erection, protrusion and thrust in breeding bulls

\begin{tabular}{|c|l|c|l|c|c|c|}
\hline Sr. & \multicolumn{2}{|c|}{ Erection score } & \multicolumn{2}{c|}{ Protrusion score } & \multicolumn{2}{c|}{ Thrust score } \\
\cline { 2 - 7 } No. & \multicolumn{1}{|c|}{ Description } & Score & \multicolumn{1}{c|}{ Description } & Score & Description & Score \\
\hline 1. & No erection & 00 & No protrusion & 00 & No thrust & 00 \\
\hline 2. & Partial erection & 01 & Partial protrusion & 01 & Weak thrust & 01 \\
\hline 3. & Fair erection & 02 & Fair protrusion & 02 & Good thrust & 02 \\
\hline 4. & Good erection & 03 & Normal protrusion & 03 & Very good thrust & 03 \\
\hline 5. & Very good erection & 04 & Abnormal protrusion & 04 & Excellent thrust & 04 \\
\hline
\end{tabular}

Table.4 Seasonal variation in score of sexual behaviour traits (Mean \pm SE) of Gir bulls during summer and winter seasons

\begin{tabular}{|l|c|c|c|c|}
\hline \multicolumn{1}{|c|}{ Traits } & Summer $(\mathbf{n = 4 8})$ & Winter $(\mathbf{n = 4 8})$ & T-value & P-value \\
\hline Temperament $(\mathbf{0 - 5}$ scale) & $1.77 \pm 0.08^{\mathrm{a}}$ & $2.08 \pm 0.06^{\mathrm{b}}$ & 3.154 & 0.002 \\
\hline Libido (0-9 scale) & $5.23 \pm 0.22^{\mathrm{a}}$ & $5.96 \pm 0.22^{\mathrm{b}}$ & 3.238 & 0.002 \\
\hline Penile erection (0-4 scale) & $2.73 \pm 0.07^{\mathrm{a}}$ & $3.02 \pm 0.06^{\mathrm{b}}$ & 3.224 & 0.002 \\
\hline Penile protrusion (0-4 scale) & $2.68 \pm 0.07^{\mathrm{a}}$ & $2.96 \pm 0.43^{\mathrm{b}}$ & 3.905 & 0.000 \\
\hline Ejaculatory thrust (0-4scale) & $3.19 \pm 0.11$ & $3.40 \pm 0.39$ & 1.479 & 0.143 \\
\hline Reaction time (sec.) & $153.54 \pm 4.82^{\mathrm{a}}$ & $128.09 \pm 4.24^{\mathrm{b}}$ & 4.028 & 0.000 \\
\hline Flehmen reaction $(\mathbf{0}, \mathbf{1})$ & $0.46 \pm 0.07$ & $0.56 \pm 0.07$ & 1.016 & 0.312 \\
\hline
\end{tabular}

Mean values having different superscript within a row differ significantly from each other at $P<0.01$ and/or at $P<0.05$. 
Table.5 Effect of seasons (summer and winter) on sexual behaviour traits (Mean \pm SE) of individual Gir bulls $(n=8$ per season)

\begin{tabular}{|c|c|c|c|c|c|c|c|c|}
\hline \multirow[t]{2}{*}{ Bull } & \multicolumn{2}{|c|}{ Temperament (0-5 scale) } & \multicolumn{2}{|c|}{ Libido (0-9 scale) } & \multicolumn{2}{|c|}{ Penile erection (0-4 scale) } & \multicolumn{2}{|c|}{ Penile protrusion (0-4 scale) } \\
\hline & Summer & Winter & Summer & Winter & Summer & Winter & Summer & Winter \\
\hline $\mathbf{1}$ & $1.75 \pm 0.16$ & $2.13 \pm 0.13$ & $2.50 \pm 0.73^{\mathrm{aX}}$ & $5.75 \pm 0.16^{\mathrm{Y}}$ & $2.12 \pm 0.13^{\mathrm{aX}}$ & $2.63 \pm 0.18^{\mathrm{aY}}$ & $2.45 \pm 0.54^{\mathrm{aX}}$ & $2.75 \pm 1.64^{Y}$ \\
\hline 2 & $1.57 \pm 0.20$ & $2.20 \pm 0.22$ & $5.57 \pm 0.20^{b}$ & $6.10 \pm 0.12$ & $2.86 \pm 0.14^{\mathrm{b}}$ & $3.20 \pm 0.12^{\mathrm{a}}$ & $2.43 \pm 0.20^{\mathrm{abX}}$ & $3.10 \pm 0.80^{Y}$ \\
\hline 3 & $1.59 \pm 0.12$ & $2.04 \pm 0.80$ & $5.45 \pm 0.22^{b}$ & $5.95 \pm 0.21$ & $2.71 \pm 0.18^{b}$ & $2.85 \pm 0.14^{\mathrm{a}}$ & $2.57 \pm 0.20^{\mathrm{b}}$ & $3.22 \pm 0.95$ \\
\hline 4 & $1.86 \pm 0.14^{\mathrm{X}}$ & $2.43 \pm 0.20^{\mathrm{Y}}$ & $5.85 \pm 0.14^{b}$ & $5.89 \pm 0.32$ & $3.12 \pm 0.09^{b}$ & $3.12 \pm 0.20^{\mathrm{a}}$ & $2.86 \pm 0.14^{b}$ & $2.98 \pm 1.02$ \\
\hline 5 & $2.14 \pm 0.34$ & $2.18 \pm 0.29$ & $6.00 \pm 0.00^{\mathrm{b}}$ & $6.04 \pm 0.11$ & $3.34 \pm 0.14^{\mathrm{bX}}$ & $3.57 \pm 0.20^{\mathrm{bY}}$ & $3.24 \pm 0.42^{b}$ & $3.02 \pm 0.74$ \\
\hline 6 & $1.57 \pm 0.20$ & $2.33 \pm 0.38$ & $5.71 \pm 0.18^{\mathrm{b}}$ & $6.20 \pm 0.25$ & $2.98 \pm 0.21^{\mathrm{b}}$ & $3.11 \pm 0.18^{\mathrm{a}}$ & $3.12 \pm 0.21^{\mathrm{b}}$ & $3.18 \pm 0.54$ \\
\hline Overall & $1.77 \pm 0.08$ & $2.08 \pm 0.06$ & $5.23 \pm 0.22$ & $5.96 \pm 0.22$ & $2.73 \pm 0.07$ & $3.02 \pm 0.06$ & $2.68 \pm 0.07$ & $2.96 \pm 0.43$ \\
\hline \multirow[t]{2}{*}{ Bull } & \multicolumn{3}{|c|}{ Intensity of thrust (0-4scale) } & \multicolumn{3}{|c|}{ Reaction time (sec.) } & \multicolumn{2}{|c|}{ Flehmen reaction $(0,1)$} \\
\hline & \multicolumn{2}{|c|}{ Summer } & Winter & Summer & \multicolumn{2}{|c|}{ Winter } & Summer & Winter \\
\hline 1 & \multicolumn{2}{|c|}{$2.63 \pm 0.18^{\mathrm{ab}}$} & $3.50 \pm 0.54^{\mathrm{ab}}$ & $142.5 \pm 8.61$ & \multicolumn{2}{|c|}{$135.00 \pm 5.35^{\mathrm{abc}}$} & $0.50 \pm 0.19$ & $0.75 \pm 0.16$ \\
\hline 2 & \multicolumn{2}{|c|}{$3.14 \pm 0.16^{b}$} & $3.29 \pm 0.18^{\mathrm{bc}}$ & $148.0 \pm 5.35$ & \multicolumn{2}{|c|}{$148.57 \pm 11.64^{\mathrm{c}}$} & $0.44 \pm 0.32$ & $0.57 \pm 0.20$ \\
\hline 3 & \multicolumn{2}{|c|}{$2.28 \pm 0.15^{\mathrm{a}}$} & $2.57 \pm 0.20^{\mathrm{a}}$ & $140.0 \pm 9.76$ & \multicolumn{2}{|c|}{$145.71 \pm 5.28^{\mathrm{bc}}$} & $0.57 \pm 0.20$ & $0.61 \pm 0.14$ \\
\hline 4 & \multicolumn{2}{|c|}{$3.71 \pm 0.22^{\mathrm{c}}$} & $3.92 \pm 0.21^{\mathrm{c}}$ & $175.71 \pm 8.96^{\mathrm{X}}$ & \multicolumn{2}{|c|}{$134.29 \pm 12.89^{\mathrm{abcY}}$} & $0.71 \pm 0.18$ & $0.59 \pm 0.28$ \\
\hline 5 & \multicolumn{2}{|c|}{$3.82 \pm 0.28^{\mathrm{c}}$} & $3.86 \pm 0.14^{\mathrm{c}}$ & $162.86 \pm 17.00^{\mathrm{X}}$ & \multicolumn{2}{|c|}{$111.43 \pm 9.37^{\mathrm{abY}}$} & $0.30 \pm 0.05$ & $0.43 \pm 0.20$ \\
\hline 6 & \multicolumn{2}{|c|}{$3.71 \pm 0.18^{c}$} & $3.57 \pm 0.30^{\mathrm{bc}}$ & $164.29 \pm 18.75^{\mathrm{X}}$ & \multicolumn{2}{|c|}{$104.29 \pm 10.66^{\mathrm{aY}}$} & $0.43 \pm 0.20$ & $0.46 \pm 0.12$ \\
\hline Overall & \multicolumn{2}{|c|}{$3.19 \pm 0.11$} & $3.40 \pm 0.39$ & $153.54 \pm 4.82$ & \multicolumn{2}{|c|}{$128.09 \pm 4.24$} & $0.46 \pm 0.07$ & $0.56 \pm 0.07$ \\
\hline
\end{tabular}

Means bearing uncommon superscript within the column (abc) and row (XY) differ significantly from each other at $P<0.01$ and/or at $P<0.05$.

Table.6 Correlation coefficients among sexual behavioural traits in Gir bulls

\begin{tabular}{|c|c|c|c|c|c|c|c|}
\hline Traits & Temperament & Libido & Penile erection & $\begin{array}{c}\text { Penile } \\
\text { protrusion }\end{array}$ & $\begin{array}{c}\text { Ejaculatory } \\
\text { thrust }\end{array}$ & $\begin{array}{c}\text { Reaction } \\
\text { time }\end{array}$ & $\begin{array}{l}\text { Flehmen } \\
\text { reaction }\end{array}$ \\
\hline Temperament & 1 & & & & & & \\
\hline Libido & 0.149 & 1 & & & & & \\
\hline Penile erection & $0.182 *$ & $0.470 * *$ & 1 & & & & \\
\hline Penile protrusion & $0.292 * *$ & $0.474 * *$ & $0.498 * *$ & 1 & & & \\
\hline Ejaculatory thrust & $0.252 * *$ & $0.218 *$ & $0.342 * *$ & $0.413 * *$ & 1 & & \\
\hline Reaction time & $-0.287 * *$ & $-0.381 * *$ & $-0.424 * *$ & $-0.364 * *$ & $-0.325 * *$ & 1 & \\
\hline Flehmen reaction & -0.144 & -0.063 & $-0.194^{*}$ & -0.055 & -0.009 & 0.021 & 1 \\
\hline
\end{tabular}

No. of observations $=96, *$ Significant at $P<0.05$ level (2-tailed), **Significant at $P<0.01$ level (2-tailed). 
The Gir bull showed normal penile protrusion throughout the study period. These findings were in consonance with those reported in Sahiwal bulls (Mandal and Tyagi, 2004; Elrabie et al., 2008; Reddy and Sasikala, 2013; Elrabie, 2017), Frieswal bulls (Mandal et al., 2008) and Kankrej bulls (Deka, 2015). However, relatively higher mean protrusion scores in crossbred bulls (Joshi and Kharche, 1992; Reddy and Sasikala, 2013), and lower scores in Sahiwal (Kumar and Nagpaul, 1995; Singh et al., 2015) and Kankrej (Rathod, 2018) bulls have also been reported by some workers.

Effect of season on protrusion score was significantly $(P<0.01)$ better during winter as compared to that of summer season, whereas no seasonal variation in protrusion score was observed in Kankrej bulls (Deka, 2015).

Rathod (2018) found significantly higher protrusion score during winter $(2.91 \pm 0.04)$ as compared to monsoon $(2.75 \pm 0.04)$ and summer (2.70 \pm 0.04$)$ season in Kankrej bulls, the present results are in agreement with his findings.

Protrusion score showed a highly significant $(P<0.01)$ positive correlation with thrust $(\mathrm{r}=0.413)$, while it had highly significant $(P<0.01)$ negative correlation with reaction time $(r=-0.364)$ and non-significant negative correlation with Flehmen reaction. A similar correlation of protrusion score with thrust has been reported in Sahiwal bulls (Kumar, 1993; Singh et al., 2015) and Kankrej bulls (Deka, 2015; Rathod, 2018), whereas the correlations of protrusion score with reaction time in Sahiwal bulls were non-significant positive (Singh et al., 2015).

Gir bulls with better penile protrusion showed the better intensity of thrust and reacted early to dummy and donated semen quickly in the present study.

\section{Intensity of Thrust}

The mean intensity of the thrust was higher in winter $(3.40 \pm 0.04)$ than during summer season $(3.19 \pm 0.11)$, however the difference was statistically non-significant (Table 4). There were significant differences $(P<0.01)$ among bulls for intensity of thrust in both the seasons (Table 5).

The Gir bulls showed a very good to excellent ejaculatory thrust during the entire experimental period. Findings observed in the study are in accordance with the observations reported in crossbred (Reddy and Sasikala, 2013) and Kankrej bulls (Deka, 2015; Rathod, 2018). However, higher intensity of ejaculatory thrust than the present one has been reported in crossbred bulls (Joshi and Kharche, 1992), while lower intensity of thrust has been documented by previous workers in Sahiwal (Kumar and Nagpaul, 1995; Mandal and Tyagi, 2004; Elrabie et al., 2008; Reddy and Sasikala, 2013; Singh et al., 2015; Elrabie, 2017), Frieswal (Mandal et al., 2008) and Murrah bulls (Kumar and Nagpaul, 1995).

Furthermore, the season showed a nonsignificant effect on mean intensity of thrust in Gir bulls, the value being higher during winter than the summer season. Similar nonsignificant seasonal variation in the intensity of thrust was also found in Kankrej bull by Deka (2015). However, Rathod (2018) found significantly higher mean intensity of thrust during winter than that of the monsoon and summer seasons.

The intensity of thrust was significantly $(P<0.01)$ negatively correlated with reaction time $(\mathrm{r}=-0.325)$ and non-significantly with Flehmen reaction. Similar correlation in Sahiwal bulls (Kumar, 1993) and in Kankrej bulls (Rathod, 2018), while non-significant negative correlations with reaction time, total 
time taken for successful mount and Flehmen reaction in Kankrej bulls (Deka, 2015) have been reported. Results indicated that Gir bulls exhibited excellent thrust, took less time to react and donate the semen.

\section{Reaction Time}

The mean reaction time (seconds) was $153.54 \pm 4.82$ and $128.09 \pm 4.24$ during summer and winter season, respectively (Table 4 ). The reaction time was observed to be significantly longer $(P<0.01)$ during summer as compared to winter season. There was significant difference $(P<0.05)$ among bulls for reaction time only in winter season, while three out of six bulls showed significant seasonal differences $(P<0.01)$ in reaction time, the values being lower in winter than summer season (Table 5).

The mean reaction time (seconds) in Gir bulls was in normal range, and it was at par with those reported in Sahiwal (Ahmad et al., 2005) and Kankrej bulls (Deka, 2015). The reaction time recorded in the present study was, however, longer as compared to those reported by others in Sahiwal (Mandal and Tyagi, 2004; Elrabie et al., 2008; Reddy and Sasikala, 2013; Singh et al., 2015; Elrabie, 2017), Frieswal (Mandal et al., 2008), Karan Fries bulls (Pal et al., 2012) and Madura bulls (Sholikah et al., 2018). While some researchers found still longer reaction time in zebu bulls like Gir, Guzerat (Kankrej) and Nellore (Daniela et al., 2008), Angus bull (Daniela et al., 2008), Cholistani bulls (Mahmood et al., 2013), Sahiwal bulls (Singh et al., 2015) and Kankrej bulls (Rathod, 2018). The result of the present experiment confirms the previous results stating that zebu bulls are slower to react to females in estrus as compared to exotic bulls, which indicates the existence of difference in genetic order in sexual behavior of these animals (Daniela et al., 2008).
The reaction time was observed to be significantly longer $(P<0.01)$ during summer than winter season. Similar results, in Sahiwal bull (Mandal and Tyagi, 2004), Cholistani bull (Mahmood et al., 2013) and Kankrej bulls (Rathod, 2018) have been reported earlier. While, a non-significant seasonal variation in Sahiwal (Ahmad et al., 2005) and Kankrej bulls (Deka, 2015) have been reported.

Reaction time (RT) had non-significant positive correlation with Flehmen reaction. These findings corroborated well with those reported in Karan Swiss (Panwar and Nagpaul, 1989), Karan Fries (Panwar and Nagpaul, 1989), Sahiwal (Panwar and Nagpaul, 1989; Kumar, 1993; Singh et al., 2015) and Kankrej bulls (Deka, 2015; Rathod, 2018).

\section{Flehmen Reaction}

Flehmen reaction facilitates olfactory and vomero-nasal organ access to body secretions, which allow the male to identify female reproductive status. Flehmen reflex exhibited by Gir bulls during different seasons were nearly similar. However, the mean frequency of Flehmen reaction was more during winter $(0.56 \pm 0.07)$ as compared to summer $(0.46 \pm 0.07)$ season (Table 4$)$. There was no significant difference among the bulls for Flehmen reaction during any of the seasons, and neither of the bulls showed variation between seasons. Similar non-significant difference, but with higher values during summer have been recently reported in Kankrej bulls (Deka, 2015; Rathod, 2018). These variations might be attributed to the difference in location, climate, species and individuality.

The mean Flehmen reaction in Gir bulls indicated lesser frequency. Gir bulls showed Flehmen reflex in one instance out of two 
collections. This might be either due to the use of recently trained bulls in the present study or due to individual differences. However, higher frequency of Flehmen response was recorded by earlier workers in crossbred bulls (Mandal et al., 2008) and Kankrej bulls (Deka, 2015), while lower frequency of Flehmen response as compared to present one have been reported in Sahiwal (Mandal and Tyagi, 2004; Elrabie et al., 2008; Pal et al., 2012; Elrabie, 2017) and Kankrej bulls (Rathod, 2018).

Association study of the sexual behaviour traits revealed a very intense relationship and opened a new way to select/reject Gir breeding bulls. Gir bulls having better temperament and libido can be selected for semen collection. The significant positive correlation among the sexual behaviour traits like temperament, libido, penile erection, penile protrusion, the intensity of thrust and negative correlation of these traits with reaction time reflected the better harmony of sexual events taking place when the bull is exposed to the dummy. Gir bulls had very good temperament and were well manageable during semen collection throughout the year with a common pattern of libido involving two false mounts before ejaculation with or without further sexual interest. Flehmen reaction was observed in single instance out of two collections. Winter was the favourable season as compared to summer for the manifestation of sexual behaviour in Gir bulls. Temperament and libido have paramount importance in Gir breeding bull due to their significant positive correlation with copulatory behaviour and negative correlation with time taken to donate semen.

\section{Acknowledgement}

The authors are thankful to the higher authorities of Junagadh Agricultural University, Junagadh for granting permission to perform the research and providing necessary facilities.

\section{References}

Adwani, R. 1992. Effect of certain managemental practices on temperament and libido of young bulls. M.V.Sc. Thesis, National Dairy Research Institute (Deemed University), Karnal, India.

Ahirwar, M.K., Kataktalware, M.A., Prasad, K., Pal, R.K., Barman, D., Thul, M. and Rawa, N. 2018.Effect of non-genetic factors on semen quality in bulls: A review. Journal of Entomology and Zoology Studies, 6(4):38-45.

Ahmad, M., Asmat, M. T. and Rehman, N. 2005.Relationship of testicular size and libido to age and season in Sahiwal bulls. Pakistan Veterinary Journal.25: 67-70.

Chenoweth, P.J. 1981. Libido and mating behavior in Bulls, Boars and Rams: A review. Theriogenology, 16: 155-170.

Daniela, S.R.B., Andre, M.J., Gilberto, P.R., Francisco, S.W. and Cristiana, A. 2008. Sexual behavior of zebu bulls and Angus at the artificial insemination center. Journal of Animal Science, 37(2): 121-123.

Deka, R. 2015. Seasonal effect on sexual behaviour in Kankrej bull.M. V. Sc. Thesis. Sardarkrushinagar Dantiwada Agricultural University, Dantiwada, Gujarat, India.

Elrabie, A.K.A. 2017.Effects of exercise on Sexual Behaviour and Semen Quality of Sahiwal bulls. International J. of Biological and Ecological Engineering, 11(8): 618-621.

Elrabie, K.A., Raina, V.S., Gupta, A.K. and Mohanty, T.K. 2008. Effect of semen collection floor on sexual behaviour and semen quality of Sahiwal bulls. Pakistan Journal of Agricultural Sciences, 45: 201205.

FAO. 2012. Milk availability trends in production, demand and medium-term outlook. Available from: http://www.dairyco.org.uk/marketinformation/supply-production/world-milk- 
production/\#_rUlMWSypo.Accessed on 28 April, 2017.

Godfrey, R.W. and Lunstra, D.D. 1989. Influence of single or multiple sires and serving capacity on mating behavior of beef bulls. Journal of Animal Science, 67: 289-297.

Hearnshaw, H. and Morris C.A. 1984. Genetic and environmental effects on temperament score in beef cattle. Australian Journal of Agricultural Research, 35: 723-33.

Joshi, V.K. and Kharche, K.G. 1992. Assessment of sexual behaviour of crossbred bulls. Livestock Advisor, 17(2): $38-41$.

Kumar, M. 1993. Sexual behaviour pattern in Sahiwal and Murrah bulls.M. V. Sc. Thesis, NDRI, Karnal.

Kumar, M. and Nagpaul, P.K. 1995. Assessment of sexual behaviour in Sahiwal and murrah bulls. Indian Journal of Animal Production and Management. 11(4): 217221.

Mahmood, S.A., Ijaz, A., Ahmad, N., Rehman, H.U., Zaneb, H. and Farooq, U. 2013.Studies on libido and serum testosterone concentration of Cholistani AI bulls.

Mandal, D.K. and Tyagi, S. 2004. Precopulatory behaviour of Sahiwal bulls during semen collection and effects of age and season on their sexual performance. Indian Journal of Dairy Science, 57(5): 334-338.

Mandal, D.K., Tyagi, S. and Kumar, M. 2008. Sexual behaviour in Holstein Friesian $\times$ Sahiwal crossbred bulls. Indian Veterinary Journal, 85(6): 636-639.

Mathur, A.K., Tyagi, S., Mukherjee, S. and Singh, S.P. 2002. Semen quality attributes in Frieswal bulls. Indian Journal of Animal
Science, 72: 59-60.

Naskar, S. and Nagpaul, P. K. 2005.Effect of social facilitation on seminal attributes and sexual behavior in crossbred male goats.Indian Journal Animal Production and Management, 19(4): 103-108.

Pal, A., Chatterjee, P.N. and Chakravarty, A.K. 2012.Genetic study of dairy cattle and buffalo bulls based on growth, milk production and reproductive traits. Iranian Journal of Applied Animal Science, 2(3): 239-245.

Panwar, P.S. and Nagpaul, P.K. 1989.Behaviour temperament and libido studies in KS bulls.Indian Journal of Dairy science, 42(4): 728-732.

Rathod, B.S. 2018. Study on Sexual Behavior, Seminal characteristics and major $H S P$ Gene in relation to fertility in Kankrej Bulls. Ph.D. Thesis. Sardarkrushinagar Dantiwada Agricultural University, Dantiwada, Gujarat, India.

Reddy, M.V.B. and Sasikala, P. 2013. Sexual behaviour of Sahiwal and Jersey x Sahiwal bulls in tropical environments at villages of Chittoor district. International Journal of Advance Science Technology Research, 3(2): 29-47.

Sholikah, N., Supriyanto, S., Yekti, A; Kuswati, S. and Susilawati, T. 2018.Sexual Behaviour and Semen Production of Madura Bulls. International Research Journal of Advanced Engineering and Science, 4(1): 48-50.

Singh, S., Bhakat, M., Mohanty, T.K., Kumar, A., Gupta, A.K., Chakravaty, A.K. and Singh, P. 2015. Sexual Behavior and its relationship with semen quality parameters in Sahiwal breeding bulls. Veterinary World, 8: 745-749.

\section{How to cite this article:}

Solanki, G.B., F.S. Kavani, S.H. Talekar, A.R. Ahlawat, H.H. Savsani and Gamit, P.M. 2019. Seasonal Influence on Sexual Behaviour Score of Gir Bulls. Int.J.Curr.Microbiol.App.Sci. 8(06): 3100-3111. doi: https://doi.org/10.20546/ijcmas.2019.806.370 